This item was submitted to Loughborough's Research Repository by the author.

Items in Figshare are protected by copyright, with all rights reserved, unless otherwise indicated.

\title{
Lost in time and space: temporal and spatial challenges facing older workers in a global economy from a career capital perspective
}

PLEASE CITE THE PUBLISHED VERSION

http://dx.doi.org/10.1080/09585192.2015.1128455

\section{PUBLISHER}

(C) Taylor \& Francis

\section{VERSION}

AM (Accepted Manuscript)

\section{PUBLISHER STATEMENT}

This work is made available according to the conditions of the Creative Commons Attribution-NonCommercialNoDerivatives 4.0 International (CC BY-NC-ND 4.0) licence. Full details of this licence are available at: https://creativecommons.org/licenses/by-nc-nd/4.0/

\section{LICENCE}

CC BY-NC-ND 4.0

\section{REPOSITORY RECORD}

Tempest, Sue, and Christine Coupland. 2019. "Lost in Time and Space: Temporal and Spatial Challenges Facing Older Workers in a Global Economy from a Career Capital Perspective”. figshare. https://hdl.handle.net/2134/20242. 


\title{
Lost in Time and Space:
}

Temporal and spatial challenges facing older workers in a global economy from a career capital perspective

International Journal of Human Resource Management

doi 10.1080/09585192.2015.1128455.

Forthcoming 2016

Sue Tempest, University of Nottingham, S.Tempest@ nubs.ac.uk

Christine Coupland Loughborough University C.Coupland@lboro.ac.uk

\begin{abstract}
This paper develops a conceptual framework to enhance our understanding of the career challenges facing older workers in a global economy. A distinction between 'high' and 'low' career capital of older workers is made. This distinction is then used to highlight potential temporal and spatial challenges for older workers in their later life careers. We draw on empirical evidence from existing studies of older workers and their careers. The contribution of this paper to human resource management debates is three-fold. Firstly, we contribute to debates in the HRM literature about intelligent careers and career capital by distinguishing between high and low career capital to explain the polarisation of older workers' careers. Secondly, we synthesise career capital issues with spatial and temporal aspects of international labour-markets to conceptualise the key issues and challenges which create potential boundaries for older workers when navigating later life careers thereby contributing to 'boundary focused scholarship' (Inkson et al., 2012: 332). Finally, we develop a series of propositions to provide a basis for further research into the issues of space and time relevant to older 'high' and 'low' career capital workers, their careers and human resource management.
\end{abstract}

Keywords: career capital; intelligent career theory; older workers' careers; time; space; boundaries; international labour markets 


\section{Lost in Time and Space: \\ Temporal and spatial challenges facing older workers and their careers in a global economy from a career capital perspective}

\section{Introduction}

Workforces in many developed nations are ageing as life expectancy rises and the age of pension eligibility is being driven upwards making 'the aging workforce .. one of the most critical theoretical and practical issues organizations face today' (Grant and Wade-Benzoni, 2009: 601). Much of the debate from policy makers in these developed countries about older workers is about extending the working life to meet economic imperatives for: individuals (around later life income and standards of living), firms (around talent shortages) and society (around pension and care costs). But policy agendas appear detached from the increasingly globally connected context for careers (Quadagno et al., 2003). We contend that the structural changes around ageing workforces in developed countries combined with more globalised career contexts have significant human resource management implications for older workers and their careers and for organisations seeking appropriate human resource practises to navigate this change.

This paper makes a contribution to conceptualising the significant career challenges facing older workers by developing researchable propositions around specific temporal and spatial challenges facing older 'high' and 'low' career capital workers' careers in an ageing society. These propositions are derived from analysis of existing literature on temporal and spatial issues in a globalised economy which we synthesise with career capital debates from the human resource management literature around 'intelligent careers'. Drawing on the career capital literature (DeFillippi and Arthur, 1994; Arthur et al., 1995) which has more significance in dynamic global business contexts (Dickmann and Doherty, 2008; Lamb and Sutherland, 2010) we introduce differential levels of career capital (high versus low) and link these to specific 
temporal and spatial issues relevant to more globalised labour markets in order to develop a richer understanding of the issues relevant to older workers' careers in those nations which are experiencing population ageing. Thus, the definition of career that we are using is one which broadly assumes that it represents the trace, or path, of the intersection of the individual with the institution of work over time.

The world's elderly population is projected to rise from $0.5 \mathrm{bn}$ in 2000 to 2 bn by 2050 (United Nations, 2008). In Japan, 44\% of the population is projected to be aged over 60 by 2050 (United Nations, 2008). Across Europe, the median age of the population is projected to rise to 52 by 2050. By $2050,37 \%$ of Russia's and 38\% of Sweden's populations are forecast to be aged 60+ (United Nations, 2015). In the US, 27\% of the population will be aged over 60 by 2050 including one million centenarians (United Nations, 2008). By 2030 more than twice as many people over 65 will reside in developing countries than developed, with China's elderly projected to total 233 million and India's 133 million (Hewitt, 2002: 485). Hence, demographic ageing is a significant phenomenon but one whose impact is most pronounced in the developed economies of Japan, Europe and the US. It is these territories we focus on to develop our conceptual framework. Further research will be needed into the specific context of older worker careers in emerging economies in Latin America, Asia and the Middle East if these populations age as predicted. Specifically research to investigate specific, local cultural differences in terms of attitudes towards seniority and younger workers would be beneficial in future.

Older workers will become more significant to ongoing productivity and innovation as they become more prevalent in developed countries (Bal et al., 2015). For the purposes of developing our argument, we draw on existing empirical studies and relevant statistics to distinguish between issues of space and time, and older workers with 'high career capital' and 'low career capital' to conceptualise the shifting nature of careers for older workers employed in developed 
ageing countries competing in a wider global economy. We then generate specific propositions as the basis for further research.

Population ageing is having significant implications for careers (Greller and Simpson, 1999; Leibold and Voelpel, 2006; Loretto and White, 2006). Population ageing has created concerns for policy makers in Western societies and Japan about dependency ratios (active workers per dependent pensioner) and for firms wishing to secure talent efficiently (Bal et al. , 2015; Hewitt, 2002; Leibold and Voelpel, 2006). Consequently, we see growing debate amongst policy makers in advanced economies about how to encourage older workers to extend their working lives (Coupland et al., 2008; Leibold and Voelpel, 2006; Riach, 2007). Yet there is a disconnect between policy makers' priority of extending working lives and the genuine challenges older workers face in their later life careers (Hirsch et al., 2000; Van Solinge and Henkens, 2007). For example, in Western contexts individual characteristics such as health, gender and caring responsibilities are particular challenges to later life careers (Flynn, 2008; Fleischmann et al., 2013; Spedale et al., 2014).

Rising dependency ratios and greater reliance on defined contribution pension schemes in developed nations increases pressure on older people to be employed for longer but global labour markets are not well suited to cope with these changes (Hirsch et al., 2000; Quadagno et al., 2003; Roberts, 2006a; Vickerstaff et al., 2008). For example, Quadagno et al. (2003) highlights how since the 1980s corporate restructuring for improved global competitiveness by firms has altered the employment of older workers. Their study of careers in the US automobile and banking industries found older workers were viewed as 'costly and untrainable' by banks. In the unionised automobile industry incentives were offered to retire and disincentives (increased overtime, defined contribution pension schemes) to remain (Quagdagno et al., 2003: 640-1). 
Empirical evidence suggests that many of the issues facing older workers in advanced nations in their later life careers are based on the structures and processes of global capitalism (Roberts, 2006a). We continue the paper by first considering general, recent developments towards a more globally connected careers' context. We then turn to the specific implications for older workers and their careers.

\section{Globally connected careers' contexts}

Globalisation combined with deregulation, the rise of emerging economies and technological change are increasing competition for firms. In response to these changes organisations are more focused upon cost efficiencies and innovation to compete. This has implications for careers in three significant ways. First, organisations focused on the cost drivers of competitiveness have sought efficiency gains from restructuring, delayering and flexible working practices (Kalleberg et al., 2000; Quadagno et al., 2003; Roberts, 2006a). Second, organisations have arguably translated market uncertainties into labour market uncertainties for individual workers (Morgan et al., 2003; Smith, 2001). This is being highlighted in public debate about whether zero-hours contracts or unpaid internships are routes to career development or exploitation? Finally, flexible working practices and global labour migration are being framed as driven by organisational demands for low cost production/service.

Thus, global competiveness pressures influence careers. Some contend that careers based on linear employment patterns in a few organisations are being replaced by more 'boundaryless' careers, which are described as flexible, transient and contractual patterns of employment that cross organisational boundaries (Arthur and Rousseau, 1996; Barley and Kunda, 2004; Iellatchitch et al., 2003; Zizic, 2015). Whilst careers are framed as more diverse and individualised and less reliant on organisations (Mayrhofer et al., 2004) this is only a partial 
picture. Critics to these boundaryless careers arguments suggest that boundaries still exist for workers but that they have been redefined (Cohen and Mallon, 1999; Dany, 2014; Duberley et al., 2006). Theoretically, careers can develop outside or across organisations via arrangements such as outsourcing, start-ups, individual consulting or temporary work. In practice, research evidence suggests that those with such careers enjoy strong professional affiliations (Iellatchitch et al., 2003; Peiperl and Baruch, 1997). These workers with scarce skills and knowledge continue to be in high demand (Barley and Kunda, 2004; Quinn, 1992). Critics highlight that the promise of boundaryless careers is not realised for low skilled workers. Evidence suggests that for such workers careers either remain bounded within organisations (De Vos and Dries, 2013) or boundaryless career becomes manifest as 'unemployment, insecurity and anxiety' (Inkson et al, 2012: 328). If old boundaries are being replaced by new ones this has implications for later life careers. Thus we contribute to this 'boundary-focused scholarship' (Inkson et al, 2012: 332) by focusing on key time and space issues which have the potential to create boundaries for older workers and their careers.

Contradictory organisational and societal demands such as those generated by globalisation can influence individual careers, thereby generating tensions which shape and drive careers (Smith, 2001). For example, organisations claim to be keen to develop and attract the best talent, but, in practice, they frequently place a significant emphasis on accessing low cost labour on a global basis. Firms are increasingly relying on virtual networks to mobilise cross-functional and crossborder expertise (Gray, 2001; Roberts et al., 1998). The internet and social media enable working practices that transcend time zones and geographic space but not all workers have the necessary skills to take advantage of them.

Internationalisation of work offers the promise of enhanced mobility (virtual and real) and greater individual agency for workers in their careers. Yet research suggests that social structure 
and individual agency are interrelated in practice (Duberley and Cohen, 2010). For example, many workers lack the power to shape their careers in terms of: role, conditions, or location as the flexible labour market literature (Arthur and Rousseau, 1996; Barley and Kunda, 2004; Iellatchitch et al., 2003) contends. This duality of labour markets has been captured in debates about 'good' jobs versus 'bad' jobs (Harrison and Bluestone, 1988; Harrison 1994; Kalleberg et al., 2000); or 'core' versus 'periphery' workers (Piore and Sabel, 1984; Pollert, 1984). Kalleberg et al. (2000) consider marginalised workers in 'bad' non-standard jobs (day labour, temporary employment, self-employment and part-time employment) and suggest that whether growth of non-standard jobs is problematic depends on the quality of these jobs. This leads us to our discussion of older workers who are at risk of marginalisation.

\section{Implications for older workers and their careers}

We now turn to the implications of more globally connected careers' contexts specifically for older workers. There is a growing debate about later life employment and careers as workforces in developed countries age (Grant and Wade-Benzoni, 2009; Hackett, 1990; Flynn, 2008). Studies point to a duality of experience for older workers in their later life careers. Older workers are particularly vulnerable to involuntary displacement from work for cost reasons by unemployment, redundancy or involuntary retirement (Hirsch et al., 2000; Roberts et al., 1998; Quadagno et al., 2003). Yet equally, highly qualified baby boomers in developed, Westernised societies have been accused of creating promotion blocks for younger workers resulting in more emphasis on horizontal careers to broaden skills rather than offer promotion (Peiperl and Baruch, 1997).

In the 1950s, Richard Titmuss (1976) identified Britain as having 'two nations in old age' based on social class. Flynn's (2008: 317-18) review of typologies of older workers suggests a division between the 'haves' (high - income, qualifications, job status) who enjoy high levels of 
job autonomy and secure pensions who can choose their later life preferences and the 'havenots' who are pushed in or out of work in response to factors beyond their control. We see evidence of polarisation of older workers into two groups but root our explanation in theoretical debates around 'intelligent career' and 'career capital' built on knowing-whom, knowing-why and knowing-how competencies which are valued in an age of knowledge-based competition (Arthur et al., 1995; Inkson, and Arthur, 2001; Zizic, 2015).

Quinn (1992) framed the concept of 'intelligent enterprise' contending that intellectual resources would become more significant for strategic management and thus HRM in an era of resource and knowledge-based competition. This focus on resources in organisations raised questions for the careers literature in terms of how, and to what extent, intellectual resources influence careers. From the resource-based view career is built upon a series of capitals (Iellatchitch et al., 2003; Zizic, 2015). Arthur et al. (1995) contended that in such a context, workers would become increasingly reliant upon their ability to build intelligent careers from three individual-level competencies namely knowing-whom, knowing-why and knowing-how competencies.

Knowing-whom is about building networks of relationships for contacts, learning and reputation via social capital (DeFillippi and Arthur, 1994; Arthur et al., 1995). Knowing-why is about the rationale and purpose of actions based on values and interests relevant to identity which shape commitment and motivation (Arthur et al., 1995; Inkson and Arthur, 2001). Knowing-how or human capital is about occupational knowledge, expertise and skills (DeFillippi and Arthur, 1994; Arthur et al., 199; Zizic, 2015). Intelligent careers are conceptualised as individualised and reliant on career capital (DeFillippi and Arthur, 1994). Career capital is defined as 'the overall set of non-financial resources a person is able to bring to his or her work' (Arthur, DeFillippi and Jones, 2001: 101). Research into the components of career capital suggest both 
tangible assets (such as qualifications, competencies, and skills) and intangible dimensions (such as emotional intelligence, opportunism and context management and adaptability) are of value in globalised labour markets (Lamb and Sutherland, 2010: 310). Career capital is viewed as an individual's property and the foundations for career success in an era when some contend that job security has been replaced by a narrative of employability (Gardner, 2005; Zizic, 2015).

For the sake of simplicity and to capture their holistic impact upon career we describe these differing, individual accumulations of knowing-whom, knowing-how; knowing-why skills as 'high' and 'low' career capital. High career capital enables us to conceptualise workers who enjoy high levels of all three forms of career capital. An example of a high career capital worker would be a highly networked, qualified, and intrinsically motivated worker whom the intelligent careers literature suggests will be better equipped to shape their career. Low career capital applies to those workers who do not enjoy high levels of all three categories of career capital. For example, in the US research into age discrimination legislation suggests that older workers with less developed career capital form an underclass on insecure 'flexible' contracts (Coupland et al., 2008; Loretto et al., 2009). Research highlights that ageing combines with other types of inequality such as race, gender, and class creating individualised career capital paths (Dugger, 1999; Spedale et al., 2014). This distinction between high and low career capital we contend enables us to begin to understand the duality of later life prospects highlighted by Titmuss in the 1950s. The addition of space and time dimensions to our distinction between 'high' and 'low' career capital offers a genuine contribution to our understanding of the polarisation of older workers' careers and the implications for human resource practices and policy.

\section{Challenges of space and time arising from careers in ageing societies}

This section of the paper develops the conceptual framework by considering time and space dimensions of international labour markets relevant to the careers of older high and low career 
capital workers. The relevance of time and space to career was derived from existing careers literature (Adam, 1988; Arthur et al, 1989; Bauman, 2001; Collin, 2000; Dany, 2014; Duberley and Cohen, 2010; Harvey, 1990; Sennett, 1999). For example, Collin (2000: 84) contends that 'time and space are implicit in career'. Time and space have interrelated impacts upon careers: 'Projections on the time dimension have an immediate effect on how careers are viewed across the social space,' (Arthur et al., 1989: 13). 'Career has thus been a means of conceptualising the individual's location in and movement through, time and space... (Collin, 2000: 85). Capitalism encourages time-space compression as organisations seek global productivity gains (Harvey, 1990). Technology de-materialises space enabling instantaneous transactions and communications that split time and space (Collin, 2000). For example, social networking in virtual space does not require shared time and space of actors. Critics contend that some of the time and space challenges arising from a globalised economy include more chaotic, fragmented and unstable societies leaving individuals 'responsible' for their individualised careers (Bauman, 2001; Sennett, 1999).

For the purposes of developing our theoretical framework along the time and space dimensions, we draw on existing theory and empirical studies to distinguish those spatial and temporal issues most relevant to the career challenges facing older workers from a career capital perspective (Arthur et al., 1995). We develop our conceptual framework by synthesising issues of time and space from the careers literature (Adam, 1988; Arthur et al, 1989; Bauman, 2001; Collin, 2000; Duberley and Cohen, 2010; Harvey, 1990; Sennett, 1999) with those issues most pertinent from the intelligent careers and career capital literatures (DeFillippi and Arthur, 1994; Arthur et al., 1995) to older low and high career capital workers and their careers. It is the synthesis of these issues which opens up new possibilities for research into understanding the challenges of later life careers. 
Careers are socially embedded in complex environments which can be framed from three levels of analysis: individual; organisational; societal (Iellatchitch et al., 2003). We focus on temporal and spatial issues at the individual level, building on our conceptualisation of 'high career capital' and 'low career capital'. However, organisational and societal actions impact upon individual careers, and therefore, all three levels of analysis are included in our conceptual framework. Having highlighted potential key temporal and spatial dimensions of careers for high and low career capital workers, we develop specific researchable propositions for future research.

The temporal and spatial dimensions of careers which have been identified by this research as most relevant to older workers' careers are outlined in Table 1. Time Control captures debates about the degree of agency older workers have over their time (Hochschild, 1997; Barley and Kunda, 2004) and considers this issue in relation to older workers and their careers. Time Acceleration draws on research which highlights our perception of the acceleration of time as we age and the re-prioritising and urgency this creates (Bal and Dorenbosch, 2015; Carstensen and Mikels, 2005; Roberts, 2006a). The Fragmentation of Career Narratives symbolises the fragmentation of careers and career narratives in contexts of short-term, flexible capitalism Sennett (1999: 133). Project Mobility captures the ability for older workers to navigate across projects for career development (Arthur, DeFillippi and Jones, 2001; Barley, Kunda, 2004). Geographic Mobility is the ability of older workers to relocate geographically for career development in a context where in many industries/sectors career progression is contingent upon mobility nationally or internationally (DeFillippi and Arthur, 1994; Dickmann and Mills, 2010). Organisational Mobility is the ability of older workers to change their organisation of employment for career progression in the face of practical constraints or age discrimination (Coupland et al., 2008; Loretto et al., 2009). Virtual Mobility is the ability of older workers to utilise digital technologies for communications and networking (Leibold and Voelpel, 2006). 
Occupational Mobility is the ability of older workers to change occupations (Hirsch et al., 2000; Lipmann et al., 2008).

\section{Insert Table One about here}

Older workers are defined herein as those aged 50 plus (Stoney and Roberts, 2003; Taylor and Walker, 1998). As workers in developed countries live longer, working lives are extending with some people working into their late 60 s and beyond. This demographic change has implications for careers. For example, ageing will make one occupational career less likely (Gray, 2001). However, stereotypes of older workers endure (Leibold and Voelpel, 2006). For example, the perception that older workers themselves are resistant to change leads to age discrimination, whereby employers avoid employing or training older workers (Lorretto and White, 2006; Taylor and Walker, 1998). Older workers receive less training than younger workers (Roberts, 2006a; Taylor and Walker, 1998) despite many older workers being open to further training. (Stoney and Roberts, 2003; Pinto, et al., 2015). Another stereotype in developed countries is that older workers perform at a lower level. Nevertheless, research suggests that there is no consistent effect of age on work performance amongst older workers (Griffiths, 2003). In practice the impact of ageing on individuals and their careers is complex and diverse (Bal, et al., 2015). For example, research on personality development suggests people become more conscientious and emotionally stable as they age (Caspi, Roberts and Shiner, 2005). Yet, stereotypes of older workers endure with implications for their career capital. This begs questions such as: to what extent can older workers retain a degree of agency and avoid peripheralisation (Coupland et. al., 2008)? We turn first to issues of time for insights.

Career is a 'time loaded' concept being an ongoing process yet reflective of past experiences, whilst future orientated, in terms of, new opportunities (Adam, 1988). Time has been linked to careers from a range of perspectives including: the lifespan approaches of career development to 
narrative interpretations focused on individual experiences of career across time (Collin, 2000). Individual experience of aging is 'time dependent' being influenced by socialisation into a given institutional era (Lippmann, 2008: 1265) generating cohorts with shared institutional experiences such as the baby boomers, born 1946-1964, who enjoyed relative affluence. For individuals, career capital has a 'temporal dimension' because it is created over time and can become an impediment in time (Duberley and Cohen, 2010: 193). For example, knowledge and skills shift in currency in response to work demands.

In terms of space, work is the spatial arena in which careers unfold: 'Work is one of the most contested domains of our social space' (Hearn and Michelson, 2006: 119). Indeed, 'spatial imagery abounds in careers discourse' in phrases such as career 'ladders', 'pathways', 'patterns' which signal a dynamic element to careers, whereby we move through social space as our careers unfold (Collin, 2000: 85). Career capital also has a spatial dimension forged from the social space of individualised career paths (Iellatchitch et al, 2003) resulting in unique knowingwhom and knowing-why career capital. The 'place' of work has been shifting given more mobile, flexible working practices. Work now extends beyond conventional domains, such as offices and factories, to include the transient domains of the train, the plane and the digital domains of virtual networks (Collin, 2000; Hearn and Michelson, 2006). Changes in work contexts arising from digital media are altering the social spaces of careers which are structured by actors with shifting power differentials (Hearn and Michelson, 2006). It is the shifting spaces of careers and the roles of older workers within them that provide the second key dimension of our conceptual framework.

Table 1 captures the time and/or space issues derived from existing literature relevant to the careers of older high and low careers capital workers. From this analysis of the existing literature and social trends a series of propositions for further empirical research are outlined in 
the next section 'analysis and discussion'. In Table 1 we outline a number of organisational level, HRM issues and societal level, policy issues arising from our research propositions as the basis for further research. These issues derived from our critical synthesis of the literature on intelligent careers, with issues of time and space, contribute a new conceptual framework to debates about career capital (knowing-why, knowing-how, knowing-whom) (DeFillippi and Arthur, 1994; Arthur, DeFillippi and Jones, 2001; Lamb and Sutherland, 2010) with specific

reference to older workers. By generating propositions for future research we contribute to crucial debates about the challenges facing older workers in extending their careers and the role of organisations and society in this process.

The issues at the individual level are presented in two columns: 'older high career capital workers' - powerful workers trading off their high career capital within or across organisations; and 'older low career capital workers' - less powerful workers, largely dependent upon organisations for work. Older high career capital workers enjoy strong reputations because they combine high levels of knowing-how human capital (qualifications, knowledge and skills from education and experience), knowing-whom - social capital (relational networks/community) and knowing-why motivation for ongoing development and learning that confers power and status (Bourdieu, 1986). Older low career capital workers have low levels of one or more dimensions of career capital making them vulnerable to the internationalisation forces shaping work careers. In the next section, we present the key time and space issues which we contend are most relevant to low and high career capital older workers careers, based on our analysis of existing literature. From this analysis we develop a series of propositions for future research.

\section{Analysis and discussion: Temporal and spatial issues facing older high and low career capital workers.}


The distinction developed herein between high career capital and low career capital when combined with dimensions of time and space makes a significant contribution to conceptualising the shifting issues of careers facing older workers competing in an increasingly international labour market. Each of the time and/or space categories summarised in Table 1 are now outlined to explain this conceptual framework.

\section{Time Control}

Capitalism is characterised by an ongoing power struggle between workers and employers over the control of time, and more specifically, its allocation to work and home life (Thompson, 1967; Barley and Kunda, 2004) as reflected in debates about 'work/life balance'. Historically, manual workers fought for specific hours of work, whilst management and professional workers were governed by professional norms of commitment. From the 1970s, some workers began to seek their own 'flexibility agenda' in response to fears about being overworked and lacking control over their time (Hochschild, 1997; Barley and Kunda, 2004). Issues of time control are acute for older workers for whom time is an especially precious and conspicuously, finite resource (Carstensen and Mikels, 2005; Bal and Dorenbosch, 2015). Studies highlight that older workers have an increased awareness of the inevitability of death via heightened mortality recognition which can in turn motivate later life decisions about how to prioritise time allocation (Grant and Wade-Benzoni, 2009; Bal and Dorenbosch, 2015).

Table 1 summarises the issues of 'time control' that are most relevant to older workers. In the cell 'older high career capital worker' and time control, we contend in proposition la: that these workers expect agency over the use of their time because it is a diminishing and finite resource. Many older high career capital workers will have accumulated sufficient financial resources to allocate their time on an 'interest basis' making ongoing work an interest driven pursuit reliant upon knowing-why motivations to sustain their career journeys. Given that 
affluence is often linked to earlier retirement (Loretto et al., 2009), organisations seeking to continue to engage high career capital older workers will need to think more creatively about how to demonstrate the rationale for continuing to work by aligning projects with the specific interests of individual, older high career capital workers.

Older low career capital workers also seek balance between their work and life commitments (Grant and Wade-Benzoni, 2009) but given their weaker career capital position this is often on a 'needs' rather an 'interests' basis. Older people increasingly face a double generational care responsibility having dependent children and very old parents to support. Increased longevity means individuals tend to have children later and/or second families. Young people are taking longer to leave home or they are returning home following college or unemployment. Older parents are living longer but are less able to live independently. Low career capital workers are more likely to face such responsibilities directly (affluent high career capital workers can afford to support their children and outsource care of older relatives to service providers). Older lower career capital workers value freedom in managing their time to meet these needs. For example, a study of older caregivers in the US found older nurses (55+) had higher participation in labour markets when offered 'caregiver friendly practices' (flexible shift scheduling, access to social workers and legal services) (Rosenfeld, 2007). Workers in this situation may face particular challenges of developing and maintaining knowing-how, knowing-whom and knowing-why career capital having less time and resources for development raising personal challenges of skills renewal, network development and motivation. Proposition 1b: Low career capital older workers seek balance in work-life commitments.

Turning now to organisational level HRM issues arising from our time control proposition, one way forward could be for organisations to offer more flexible and varied working opportunities for older workers including phased transitions to retirement such as 'bridge employment'. 
Bridge employment is 'employment that takes place after a person's retirement from a full-time position but before the person's permanent withdrawal from the workforce' (Kim and Feldman, 2000: 1195; Pinto et al., 2014). Bridge employment may be easier for high career capital older workers to obtain thereby offering agency in their career paths. For example, Rau and Adams (2005) studied bridge employment in the context of university workers and found that advertising flexible working was attractive to older recruits, especially when offered with mentoring roles.

Support from organisations for longer careers offers workers agency over retirement timing (Van Solinge and Henkens, 2007) which in turn contributes to the psychological well-being of older people (De Vaus et al., 2007). In the West, between 10-50\% of retirement is estimated to be involuntary, with retirement 'decisions' being socially embedded rather than individual choices (Van Solinge and Henkens, 2007). Renewing individual career capital is vital to ongoing employability and career development in an age of intelligent enterprise (Quinn, 1992). Older workers employed by organisations receive less training than younger workers (Bal and Dorenbosch, 2015; Loretto et al., 2009). For older high career capital workers continual professional development is vital to an extended career as work practices, knowledge and supporting technologies are changing rapidly in many sectors. For lower career capital workers equality of opportunity and time for training relative to their younger peers are important issues.

The societal level policy issues arising from our time control propositions are now considered. In advanced Western nations it has been noted that pension policy is being used to encourage later retirement. For high career capital workers ongoing fulfilment in prestigious roles may be conducive to an extended working life. An extended working life may be more problematic for older low career capital workers who may be in jobs that require physical strength (e.g. firemen) or high productivity (e.g. call centre workers). Additionally, active older people have 
traditionally fulfilled vital unpaid social roles as voluntary workers and carers to partners and grandchildren (Coupland et al., 2008). Wider social engagement may be required by more, younger people to plug this gap if older workers retire later.

\section{Time Acceleration}

Time acceleration is the next key time/space issue relevant to older workers' careers in Table 1. Older people perceive time passing faster as they age (Bal and Dorenbosch, 2015; Carstensen and Mikels, 2005; Roberts, 2006a). This time acceleration is compounded by digitally mediated work spaces that support spatially dispersed virtual communities which have also been associated with a perception that time is accelerating - sometimes described as 'fast capitalism' (Roberts, 2006a: 633).

The cell for older high career capital workers introduces proposition $2 a$ : that facing time acceleration, the resultant sense of urgency will make such workers more discerning in what they will commit to. Knowing-why motivations may come to the fore for such workers seeking legacy opportunities from meaningful later life projects. Older creative workers such as artists, writers or composers often produce their best work towards the end of their life (in their $60 \mathrm{~s}$, 70s or even 80s) (Grant and Wade-Benzoni, 2009; Simonton, 1988). This suggests that such workers have the potential to make valuable, high level, contributions but on their own terms, which raises challenges for human resource management. Knowing-whom and associated knowing-how considerations, such as working with influential collaborators or rising talent with new skills may also become important making them more selective in their projects.

Older low career capital workers face time acceleration too but from a less positive position in the labour market because they lack the career capital necessary for career agency. In terms of their knowing-how and knowing-whom career capital, such workers face a higher risk of their 
skills and contacts becoming redundant over time making them more vulnerable to workplace displacement as they age (Loretto et al., 2009).

In terms of organisational level HRM issues arising from time acceleration, firms are under pressure to raise productivity and innovation by managing knowledge (Spender, 1996) and fastcapitalism places emphasis on personal networks (knowing-whom) (Roberts, 2006b) for learning. The social capital of older high career capital workers is well developed (Knight and Yeuh, 2008) and valued. For example, a survey of HR Executives of large, US companies found $60 \%$ of respondents were concerned about a 'brain drain' caused by retiring talent (Arnone, 2006). To extend the working lives of high career capital workers interesting/status projects may be necessary to secure their commitment. For low career capital workers as they age they may feel 'disposable' and more dependent on their employer. This uncertainty about the future may lead to emotional issues of anxiety and disengagement which may need support.

At the societal level, if older people are to be encouraged to delay retirement we may need cultural change in developed countries. Seniority and wisdom are valued in some societies. For example, the Chinese system of guanxi places a high premium on the social capital of elders (Knight and Yueh, 2008). In Western, developed nations youth culture pervades many industries and is reinforced by the media. Developed societies may benefit from adopting a more positive narrative of later life as reflected in the language of 'elders' and 'sages' to support later life careers.

\section{Fragmentation of Career Narratives}

The next dimension of time relevant to careers in an ageing society, as summarised in Table 1, is the 'fragmentation of career narratives'. Career has been conceptualised as a 'narrative of mastery' by social commentators such as Lippmann, Weber and E.P. Thompson as an antidote 
to aimlessness (Sennett, 1999). Short-term flexible capitalism has made sustaining coherent career narratives over extended working lives challenging. Employment data combined with evidence of age discrimination at work suggests securing continuity and meaning in our careers is problematic as we age. Age discrimination is the most commonly experienced form of discrimination with $23 \%$ of people reporting experiencing it in some form (Age Concern, 2009). Older workers are particularly vulnerable to restructuring, being passed over for promotion or being excluded from training (Loretto et al., 2009). High career capital workers are not insulated from the fragmentation of career narratives, as 'good jobs' have been restructured away, or outsourced (Sennett, 1999: 119; Smith, 2001). Nevertheless, in Europe older workers with the highest qualifications are most likely to work (Loretto et al., 2009: 3). Such employability evidence leads us to proposition $3 a$ : that older high career capital workers are better placed to forge a coherent sense of career built on opportunity recognition and realisation, which enables them to protect their sense of identity as they age. This advantage we suggest reflects their strong individual expertise (knowing-how career capital) and well developed social networks (knowing-whom career capital) forged through their extensive career journey.

Proposition 3b: suggests that older low career capital workers who have experienced more discontinuous and uncertain careers may find sustaining meaningful career narratives more challenging. For older low career capital workers weaker networks from more disjointed career journeys limit knowing-whom career capital making navigation between career opportunities difficult. This career disadvantage may reduce their ability to renew their knowing-why motivation and knowing-how knowledge and skills.

Our propositions suggest that the fragmentation of career narratives can threaten organisational memory with implications for learning and innovation. Older workers can offer insights into contextual issues of past, present and future opportunities and threats. Older high career capital 
workers enjoy strong knowing-whom social capital and knowing-how human capital (Bourdieu, 1986) making them helpful in identifying issues arising from contextual change. Extending these insights to society at large, there may be benefit from enhanced contextual understanding in terms of highlighting what is evolutionary, cyclical or revolutionary for society if we can engage older workers in a broader dialogue about emergent issues. From such dialogue we may embed the lessons of history for ongoing learning. Such learning is crucial in a digital age where wider communication of events does not automatically result in shared learning. For example, the lessons of tribal people were passed down for millennia by stories told by their elders for the benefit of future generations, yet in the $21^{\text {st }}$ century we failed to learn from the banking crisis in Japan in the 1990s. Such learning arguably could have helped us avoid a global banking crisis a mere decade later.

The second set of time and space issues arising from our research which are relevant to older workers' careers are 'mobility issues' as outlined in Table 1. Mobility issues are particularly challenging in contexts of ageing because the global economy trades on mobility advantages. 'The new hierarchy of power is marked at the top by the ability to move fast and at short notice, and at the bottom by the inability to slow down those moves, let alone arrest them, coupled with its own immobility.' (Bauman 2001: 35) or put another way people face a social context of work where 'to stay put is to be left out' (Sennett, 1999: 87). Older low career capital workers are vulnerable to being left behind spatially and temporally in the physical and virtual worlds of work. For example, research suggests that older workers displaced from blue collar jobs are unemployed longer than older workers in professional, technical and service jobs (Lippmann, 2008). Older low career capital workers are vulnerable to becoming trapped in adverse social conditions. Policy objectives of extended working lives are reliant upon older workers being mobile within and across: projects; geographic territories; organisations, virtual worlds, and 
occupations. We need to know more about how such mobility is constrained boundaries, in practice, in a society where older workers are more prevalent.

\section{Project Mobility}

The first issue of mobility highlighted in Table 1 is 'project mobility'. The ability to navigate across projects is vital to career development (Arthur, DeFillippi and Jones, 2001; Barley, Kunda, 2004) but the power to be 'mobile' is disproportionately held by the elites (Bauman, 2001; Gray, 2001). This leads us to proposition 4a: that older high career capital workers are more likely to be aware of, or approached about, new projects enabling high project mobility. Project mobility facilitates the ongoing development of occupational networks for knowingwhom and knowing-why career capital renewal, and learning for knowing-how career capital development. High career capital older workers we contend will be more selective in deciding which projects to pursue based upon legacy and reputation building priorities (Grant and WadeBenzoni, 2009) making knowing-why motivations central to their career journeys.

Older low career capital workers face project mobility constraints which could undermine the development of knowing-how, knowing-why and knowing-whom career capital. For example, a comparative case study of the banking and automobile industries, in the US, found a lack of worker retraining programmes for low career capital workers who were treated as immobile liabilities as noted by a Vice President informant: 'Many older people near retirement are just left here. It's not worth getting rid of them because of the potential age discrimination problem' (cited in Quadagno et al., 2003: 648). This leads to proposition 4b: that lower project mobility for low career capital workers reduces their rate of career capital development and renewal making them more dependent on their existing employer for opportunities. 
For organisations, given propositions $4 \mathrm{a}$ and $4 \mathrm{~b}$, an ageing workforce raises specific implications for the human resource management of project based work. Older high career capital workers are more selective in the projects they are willing to engage with. This issue makes building teams with strong social capital and high trust challenging if older high career capital workers are perceived as 'cherry picking' the work they will do. Older low career capital workers are more likely to be excluded from challenging projects leading to the risk of 'experience discrimination' undermining the career capital they can bring to specific projects in terms of knowing-how, knowing-whom with implications for their knowing-why motivation.

At the societal level, raising career capital supports project mobility. More flexible educational and training options for older workers may be beneficial given the growing importance of ongoing learning to later life careers, especially for workers with wider family/care responsibilities (Hirsch et al., 2000; Loretto et al., 2009). More flexible tax and benefit systems could help older workers to migrate more readily back and forth between work, underemployment, and unemployment (Leibold and Voepel, 2006; Loretto et al., 2009) to pursue more diverse projects, some of which may be on short-term contracts. The next dimension of mobility featured in Table 1 is geographic mobility.

\section{Geographic Mobility}

Career development in many industries relies on geographic mobility (DeFillippi and Arthur, 1994; Dickmann and Mills, 2010) and raises critical issues about how individual career strategies interact with organisational priorities. For older workers particular issues may arise. Older workers may be more emotionally attached to their existing home locations due to embedded family or social connections. Older workers who are receptive to geographic mobility for work face practical challenges. For example, older workers can become trapped in a locality because of house price differentials across different geographic regions which cannot be 
navigated because mortgages remain modelled upon fixed retirement ages. The rigidity of mortgage products mean that buying and selling a home to relocate in later life is problematic because available mortgage repayment periods are reduced as we age inflating mortgage costs.

Older high career capital workers are more affluent and this leads to proposition 5a: that such workers enjoy higher levels of geographic mobility. They may achieve geographic mobility by multiple homes or by greater reliance on travel or virtual communication if they have family ties, health issues or other ties of place. Proposition 5b: contends that older low career capital workers are at more risk of being financially trapped in geographic locations which may restrict the scope of their careers in terms of knowing-whom and knowing-how exposure to new networks, cultures, knowledge etc.

Organisations can act as powerful advocates of policy change and they could be making more of an impact here for societal change. At a societal level, geographic mobility constraints for older low career capital workers can create generational ghettos whereby older people become concentrated in specific geographic areas, such as old industrial centres. Policy makers could do more to safeguard age diverse communities and encourage financial service providers to offer more age friendly financial instruments for house purchase, pension portability and care to support career development in later life. However, even at the local level older workers face challenges of mobility in terms of restrictions upon organisational mobility.

\section{Organisational Mobility}

The ability for older workers to move between organisations for career development can be restricted by various factors including geographic reasons (as previously discussed) and reasons of age discrimination. For high career capital workers, organisational mobility may be constrained by the contraction of and competition for 'good jobs' (Smith, 2001). Proposition 
6a: suggests that older high career capital workers have agency over job moves because they are valued in terms of their well developed career capital. Older high career capital workers also have knowing-whom contacts to facilitate career moves or develop a portfolio of work across organisations. Older low career capital workers appear more practically constrained in their ability to find a new job (due to discrimination in the labour market), as reflected in proposition $6 b$ in Table 1, making them particularly vulnerable to restructuring or career stagnation from diminishing career capital.

As the proportion of younger workers declines in ageing societies, the case for the retention of older workers becomes more compelling for organisations. At the societal level, age discrimination legislation is the starting point for addressing these issues but practical constraints need addressing too, such as pension portability. In addition to physical mobility older workers also face new challenges of virtual mobility in their later life careers.

\section{Virtual Mobility}

Work has become more reliant on digital technologies for communications and networking. A number of studies have found that age is not directly linked to the adoption of digital technologies (Leibold and Voelpel, 2006). Despite the stereotype of older people as less adept technologically, in practice, people's access to digital technology depends on social structure, individual attitudes and lifelong habits rather than age (Peace et al., 2007). Thus we contend in proposition 7a: that older high career capital workers have a strong rationale for investing in their technological capital because web-based technologies and social media enable selfpromotion and networking for knowing-whom renewal on a global basis. International networks offer access to knowing-how insights about cultural differences of professional practice across territories and facilitate exposure to new ideas for knowing-why refreshment. 
By contrast proposition $7 b$ : suggests that older low career capital workers may be more reliant on their employers for access to the latest technologies and may require adaptations to IT to improve access plus training into how technology can be applied to their work. Older low career capital workers with training and equipment may also be able to link into wider occupational networks to develop contacts beyond their employer for learning and to access opportunities. For organisations, investments in technology help to address many of the mobility challenges faced by older workers in the physical word by enabling virtual networking and learning across time and space. At the level of the state, more could be done to promote digital inclusion to support later life careers. The final category of mobility relevant to later life careers is occupational mobility.

\section{Occupational mobility}

As working lives extend occupational change at some stage in our careers becomes more likely. Proposition 8a: highlights that, older high career capital workers because of their high skills are more likely to be able to navigate towards new occupational opportunities as industry and occupational boundaries shift. However, the decline in 'good jobs' means competition for positions in expanding sectors is likely to intensify making the transferability of knowing-whom contacts and knowing-how knowledge to different occupational arenas an important consideration for such workers.

Older low career capital workers face significant constraints in changing occupations. These limitations include: the broader stereotypes of older workers; mobility constraints previously discussed; practical constraints around limited access to retraining for occupational change given implicit upper age limits in some occupations or prohibitively high costs of retraining. Survey data in the US suggests substantial entry barriers for older workers in occupations with steep age profiles, pension benefits and computer usage (Hirsch et al., 2000). Older workers 
facing low career capital may find that trying to change occupation is beneficial to knowingwhy motivation. But to realise this ambition may require considerable support and guidance from wider support agencies as reflected in proposition $8 b$.

Organisations can benefit from older career changers as the proportion of younger recruits falls. For example, some mid career financial service workers, displaced by the credit crunch, have retrained as teachers in the UK. At the societal level, cultural change can support career change in later life. For example, in Japan the government is encouraging later life career change to be viewed as 'normal' by investing significantly in 'silver human resource centres', which deliver support and advice to jobseekers over 60 (Flynn, 2014). Lippmann (2008: 1285) analyses data on occupation switching and finds 'the era and institutional milieu in which one was born appears to explain much of the difficulty older workers have in becoming re-employed.' This suggests that the scope for societal level influence upon attitudes to career change is high if supported by practical changes as outlined in Table 1.

\section{Conclusions and implications for future research}

The theoretical contribution of this paper to human resource management literature is three-fold. Firstly, we contribute to debates in the HRM literature about intelligent careers and career capital (DeFillippi and Arthur, 1994; Arthur et al., 1995) by extending the conceptualisation of career capital to encompass issues specifically relevant to older workers' careers. Our distinction between 'high' and 'low' career capital offers a basis to begin to understand the polarisation of older people's later life careers in developed, ageing societies. Secondly, we synthesise career capital issues with spatial and temporal aspects of international labour-markets to conceptualise the key issues and challenges relevant to older workers when navigating their later life careers. This analysis identifies a series of potential temporal and spatial boundaries which are a particular risk to low career capital workers' careers. Finally, from this conceptual 
framework we develop a series of researchable propositions to provide a basis for further research into the issues of space and time relevant to older 'high' and 'low' career capital workers, their careers and human resource management theory and practice.

In summary it is our aim to develop a more sophisticated understanding of older workers and their specific career challenges by applying the theory of intelligent careers and career capital (DeFillippi and Arthur, 1994; Arthur et al., 1995) to the conceptualisation of later life careers shaped by differential levels of career capital (high verses low) and time and space dimensions. In the paper specific spatial and temporal issues are introduced and synthesised with career capital differentials in order to offer a more nuanced conceptual framework from which future studies into later life career might build. By providing this framework which connects and synthesises spatial and temporal issues with distinctions between high and low career capital the paper may serve as a useful guide for future empirical research.

We intend that our conceptual paper will act as a catalyst for further research into the polarised challenges older workers face in their later life careers. A key concern is that workers become increasingly path dependent upon the career capital development and renewal during their working lives. It has been suggested that older high career capital workers enjoy more agency in their careers, and opportunities to reinforce and renew their knowing-whom, knowing-how and knowing-why career capital. By contrast, older workers with low career capital are particularly at risk of becoming 'lost in time and space' in career terms if they are more limited in opportunities for career capital development and renewal, with significant limiting implications for their later life career journeys. This analysis supports research by others which suggests that the impact of career capital is cumulative - 'showing its dark side' characterised by 'temporal dynamism' (Duberley and Cohen, 2010: 195-196) however, our propositions suggest that more 
could be done to support older worker' ongoing career capital development by organisations and society.

A richer insight into the nature of older worker's careers is timely and relevant given ageing populations in many developed countries. We suggest if workers in these countries are to be encouraged to work for longer they need more support from organisations in terms of human resource practices and policies. This paper builds from existing studies into ageing in developed Westernised societies. Further research exploring the impact of different cultural settings on later life careers would also be beneficial as more emerging economies begin to experience population ageing during this century.

It has been claimed that: "Globalisation has transformed the structure of capitalism in both time and space, generating direct implications for workers with the ability to access a range of labour market spaces and for employers to draw on a ready source of labour internationally" (Herod, 2001: 407). Nevertheless, we have highlighted that genuine time and space constraints have the potential to impact upon older workers' careers. Older workers can contribute valuable knowledge, skills, historical/contextual insights and networks of contacts (Leibold and Voelpel, 2006) to organisations. Organisations risk losing such knowledge in 'time' and 'space' if older workers become marginalised from career capital development and renewal as they age. Avoiding this risk requires human resource management practises that address the needs of both 'high' and 'low' career capital workers. Further research into the career capital of older workers combined with the temporal and spatial boundaries such workers face offers the prospect of impactful insights into the genuine challenges of maintaining later life careers in an era of ‘intelligent enterprise’ (Quinn, 1992). 


\section{References}

Adam, B. (1988), 'Social versus natural time, a traditional distinction re-examined', in The Rythms of Society, ed. M. Young \& Schuller, T. London: Routledge.

Age Concern, (2009), 'Older worker job losses'. www.ageconcern.org.uk/AgeConcern/joblosses-release-210109.asp, 14.11.09.

Arnone, W. (2006), 'Are employers prepared for the aging of the US workforce?', Benefits Quarterly, 4, 7-12.

Arthur, M., Claman, P., DeFillippi, R. (1995), 'Intelligent enterprise, intelligent careers', Academy of Management Executive, 9, 4, 7-20.

Arthur, M.B., DeFillippi, R.J., Jones, C. (2001), 'Project-based learning as the interplay of career and company non-financial capital,' Management Learning, 32, 1, 99-117.

Arthur, M., Hall, D., Lawrence, B. (1989), 'Generating new directions in career theory: The case for a transdisciplinary approach', in Handbook of career theory, ed. M. Arthur, Hall, D. \& Lawrence, B., Cambridge, Cambridge University Press, 7-25.

Arthur, M., Rousseau, D. ed (1996), The boundaryless career: A new employment principle for a new organizational era, New York: Oxford University Press.

Bal, P., Dorenbosch,L. (2015), 'Age-related difference in the relations between individualised HRM and organisational performance: a large-scale employer survey', Human Resource Management Journal, 25, 1, 41-61.

Bal, P., Van Kleef, M,. Jansen, P. (2015), 'The impact of career customisation on work outcomes: Boundary conditions of manager support and employee age', Journal of Organizational Behaviour, 36, 421-440.

Barley, S., Kunda, G. (2004), Gurus, hired guns and warm bodies: Itinerant experts in a knowledge economy, Oxford: Princeton. 
Bauman, Z. (2001), The individualized society, Cambridge: Polity.

Bourdieu, P. (1986), 'The forms of capital', in Handbook for theory and research for the sociology of education, ed. J.G. Richardson, New York: Greenwood Press, 241-258.

Carstensen, L., Mikels, J. (2005), 'At the intersection of emotion and cognition: aging and the positivity effect, Current Directions in Psychological Science, 14, 3, 117-121.

Caspi, A., Roberts, B., Shiner, R. (2005), 'Personality development: Stability and change', Annual Review of Psychology, 56, 453-484.

Cohen, L., Mallon, M. (1999), 'The transition from organisational employment to portfolio working: Perceptions of Boundaryless', Work, Employment \& Society, 13, 2, 329-352.

Collin, A. (2000), 'Dancing to the music of time', in The future of career A. Collin, \& Young, R., ed, Cambridge: Cambridge University Press.

Coupland, C., Tempest, S., Barnatt, C. (2008), 'What are the implications of the new UK age discrimination legislation for research and practice?' Human Resource Management Journal, $18,4,432-431$.

Dany, F. (2014), 'Time to change: the added value of an integrative approach to career research', Career Development International, 19, 6, 718-730.

DeFillippi, R., Arthur, M. (1994), The Boundaryless Career: A competency based perspective,' Journal of Organisational Behaviour, 15, 2, 307-324.

De Vaus, D., Wells, Y., Kendig, H., Quine, S. (2007), 'Does gradual retirement have better outcome than abrupt retirement? Results from an Australian panel study,' Ageing \& Society, 27, 667-682.

De Vos, A., Dries, N., (2013), 'Applying a talent management lens to career management: the role of human capital composition and continuity,' The International Journal of Human Resource Management, 24, 9, 1816-1831. 
Dickmann, M., Doherty, N. (2008), 'Exploring the career capital impact of international assignments within distinct organisational contexts,' British Journal of Management, 19, 145161.

Dickmann, M., Mills, T. (2010), 'The importance of intelligent career and location considerations: Exploring the decision to go to London', Personnel Review, 39, 10, 116-134.

Duberley, J., Cohen, L. \& Mallon, M. (2006), 'Constructing scientific careers: change, continuity and context', Organization Studies, 27, 8, 1131-1151.

Duberley, J., Cohen, L. (2010), 'Gendering career capital: An investigation of scientific careers', Journal of Vocational Behaviour, 76, 187-197.

Dugger, W. (1999), 'Old age is an institution', Review of Social Economy, 52, 1, 84-98.

Emmison, M., Frow, J. (1998), 'Information technology as cultural capital', Australian Universities Review, 1, 41-45.

Fleischmann, M., Koster, F., Dykstra, P., Schippers, J. (2013), 'Hello pension, goodbye tension? The impact of work and institutions on older workers' labor market participation in Europe,' International Journal of Ageing and later Life, 8, 2, 33-67.

Flynn, M. (2008), 'Who would delay retirement? Typologies of older workers', Personnel Review, 39, 3, 308-324.

Fynn, M. (2014), 'Lessons from Japan: helping the older unemployed back into work', The Guardian, $\quad$ http://www.theguardian.com/careers/careers-blog/retirement-ageing-workforcejapan-jobs, Accessed 5.09.15.

Gardner, T.M. (2005), 'Human resource alliances: Defining the construct and exploring the antecedents', The International Journal of Human Resource Management, 16, 6, 1049-1066. 
Grant, A., Wade-Benzoni, K. (2009), 'The hot and cool of death awareness at work: Mortality cues, aging and self-protective and prosocial motivations', Academy of Management Review, $34,4,600-622$.

Gray, J. (2001), 'The end of career', Communications of the ACM, 44, 11, 65-69.

Greller, M., Simpson, P. (1999), 'In search of late career: A review of contemporary social science research applicable to the understanding of late career', Human Resource Management Review, 9, 309-347.

Griffiths, A. (2003), 'Performance of older workers', in Kumashiro, M. (eds) Ageing and Work, London: Taylor-Francis.

Hackett, R. D. (1990), ‘Age, Tenure and Employee Absenteeism', Human Relations, 43, 7, 601620.

Harrison, B. (1994), Lean and mean: The changing landscape of corporate power in the age of flexibility, New York: Basic Books.

Harrison, B., Bluestone, B. (1988), The great u-turn: Corporate restructuring and the polarising of America, New York: Basic Books.

Harvey, D. (1990), The condition of post-modernity, Cambridge MA: Blackwell.

Hearn, M. Michelson, G. ed (2006), Rethinking work: Time, Space and Discourse, New York: Cambridge University Press.

Herod, A. (2001), 'Labour internationalisation and the contradictions of globalisation: or why, the local is still important in a global economy', Antipode, 33, 3, 407-426.

Hewitt, P. (2002), 'Global aging and the rise of the developing world', The Geneva Papers on Risk and Insurance, 27, 4, 477-485. 
Hirsch, B., Macpherson, D.A., Hardy, M. (2000), Occupational age structure and access for older workers, Industrial and Labour Relations Review, 53, 3, 401-418.

Hochschild, A. (1997), The Time Bind: When work becomes home and home becomes work, New York: Metropolitan Books.

Iellatchitch, A., Mayrhofer, W., Meyer, M. (2003), 'Career fields: a small step towards a grand career theory?' International Journal of Human Resource Management, 14, 5, 728-750.

Inkson, K., Arthur, M.B. (2001), 'How to be a successful career capitalist,' Organisational Dynamics, 30, 1, 48-61.

Inkson, K., Gunz, H., Ganesh, S., \& Roper, J. (2012), 'Boundaryless careers; Bringing back boundaries,' Organization Studies, 33, 3, 323-340.

Kalleberg, A.L., Reskin, B.F., Hudson, K. (2000), 'Bad jobs in America: Standard and nonstandard employment relations and job quality in the United States' American Sociological Review, 65, 2, 256-278.

Kim, S. Feldman, D.C. (2000), 'Working in retirement: The antecedents of bridge employment and its consequences for quality of life in retirement', Academy of Management Journal, 43, 6, 1195-1210.

Knight, J., Yueh, L., (2008), 'The role of social capital in the labour market in China', Economics of Transition, 16, 3, 389-414.

Lamb, M., Sutherland, M. (2010), 'The components of career capital for knowledge workers in the global economy', The International Journal of Human Resource Management, 21, 3, 295312.

Leibold, M., Voepel, S. (2006), Managing the aging workforce: Challenges and solutions, Germany: Wiley. 
Lippmann, S. (2008), 'Rethinking risk in the new economy: Age and cohort effects on unemployment and re-employment', Human Relations, 61, 9, 1259-1292.

Loretto, W., White, P. (2006), 'Employers' attitudes, practices and policies towards older workers', Human Resource Management Journal, 16, 3, 313-330.

Loretto, W., Vickerstaff, S., White, P. ed (2009), The Future for older workers: New perspectives, Bristol: The Policy Press.

Mayrhofer, W., Iellatchitch, A, Meyer, M., Steyrer, J.; Schiffinger, M., Strunk, G. (2004) 'Going beyond the individual: Some contributions from a career field and habitus perspective for global career research and practice', Journal of Management Development, 23, 9, 870-884.

Morgan, G., Kelly, B., Sharpe, D., Whitley, R. (2003), 'Global managers and Japanese multinational: Internationalisation and management in Japanese financial institutions', International Journal of Human Resource Management, 14, 3, 389-407.

Peace, S., Wahl, H. W., Mollenkopf, H., Oswald, F. (2007), 'Environment and ageing' in Ageing in Society, ed, J. Bond, Peace, S., Dittmann-Kohli, F., Westerhof, G., London: Sage.

Peiperl, M., Baruch, Y. (1997), 'Back to Square Zero: The post corporate career', Organizational Dynamics, Spring, 7-22.

Pinto, A., da Silva Ramos, S., Nunes, S. (2014) 'Managing an aging workforce: What is the value of human resource management practices for different age groups of workers?', TekhneReview of Applied Management Studies, 12, 58-68.

Piore, M., Sabel, C. (1984), The second industrial divide: Possibilities for prosperity, New York: Basic Books.

Pollert, A. (1984), 'The 'Flexible Firm': Fixation or Fact?' Work, Employment and Society, 2, 3, 281-316. 
Quadagno, J., Hardy, M., Hazelrigg, L. (2003), 'Labour Market Transitions and the erosion of the Fordist Lifecycle: Discarding Older workers in the automobile and banking industries in the United States', The Geneva Papers on Risk and Insurance, 28, 4, 640-651.

Quinn, J. (1992), 'The intelligent enterprise a new paradigm', Academy of Management Perspectives, 6, 4, 48-63.

Rau, B.L., Adams, G.A. (2005), 'Attracting retires to apply: Desired organisational characteristics of bridge employment', Journal of Organizational Behaviour, 26, 649-660.

Riach, K. (2007), 'Othering' older worker identity in recruitment', Human Relations, 60, 11, 1701-1726.

Roberts, I. (2006a), 'Taking age out of the workplace: putting older workers back in?', Work Employment and Society, 20, 1, 67-86.

Roberts, J. (2006b), 'Limits of communities of practice', Journal of Management Studies, 43, 3, 623-639.

Roberts, K., Kossek, E., Ozeki, C. (1998), 'Managing the global workforce: challenges \& strategies', Academy of Management Executive, 12, 4, 93-106.

Rosenfeld, P. (2007), 'Workplace practices for retaining older hospital nurses: implications from a study of nurses with eldercare responsibilities', Policy, Politics and Nursing Practice, 8, $2,120-129$.

Sennett, R. (1999), The Corrosion of Character, New York: Norton.

Simonton, D.K. (1988), 'Age and outstanding achievement: What do we know after a century of research?', Psychological Bulletin, 104, 251-267.

Smith, V. (2001), Crossing the Great Divide: Worker risk and opportunity in the New Economy, New York: Cornell University Press. 
Spedale, S., Coupland, C. \& Tempest, S. (2014) 'Gendered ageism and organizational routines at work: The case of day-parting in television broadcasting,' Organization Studies, 35, 11: 1585-1604.

Spender, J.C. (1996), 'Making knowledge the basis of a dynamic theory of the firm,' Strategic Management Journal, 17, 45-62.

Stoney, C., Roberts, M. (2003), 'The case of older workers as Tesco: An examination of attitudes, assumptions \& Attributes', Working Paper 53, Canada: Carleton University School of Public Policy and Administration.

Taylor, P., Walker, A. (1998), 'Policies and practices towards older workers - a framework for comparative research,' Human Resource Management Journal, 8, 3, 61-76.

Thompson, E. P. (1967), 'Time, work discipline \& industrial capitalism', Past and Present, 38, 56-97.

Titmuss, R. M. (1976), Essay on 'The Welfare State', ( ${ }^{\text {rd }}$ Edition) London: Allen \& Unwin.

United Nations (2008), 'United Nations Populations Statistics', http://unstats.un.org/unsd/demographic/, 15.07 .08

United Nations (2015), 'United Nations Population Statistics -World Ageing by Nation', www.un.org/esa/publication 6/ world aging/, 09.11.15

Van Solinge, H., Henkens, K. (2007), 'Involuntary retirement: The role of restrictive circumstances, timing and social embeddedness', Journal of Gerontology, Series B, Psychological Sciences and Social Sciences, 62B, 5, S295-S303.

Vickerstaff, S., Loretto, W., Billings, J., Brown, P., Mitton, L., Parkin, T., White, P. (2008), 'Encouraging labour market activity among 60-64 year olds', Department for work and pensions, Norwich. 
Zizic, J. (2015), 'Skilled migrants' career capital as a source of competitive advantage: implications for strategic HRM', The International Journal of Human Resource Management, $26,10,1360-1381$. 